\title{
Evolution of the Efficiency of Nationwide Commercial Banks in China Based on an SBM-Undesirable Model and DEA Window Analysis
}

\author{
Lei Guo $\mathbb{D}^{1,2}$, Sanggyun Na ${ }^{1},{ }^{2}$ Xianhua Tan $\mathbb{D}^{2,3}$ Pengfei Gui, ${ }^{2}$ and Congchong Liu ${ }^{2}$ \\ ${ }^{1}$ School of Accounting, Jiujiang University, Jiujiang 332005, China \\ ${ }^{2}$ School of Business Administration, Wonkwang University, Iksandae-ro 460, Iksan, Jeonbuk 54538, Republic of Korea \\ ${ }^{3}$ School of Economics and Management, Shangrao Normal University, Shangrao 334001, China
}

Correspondence should be addressed to Sanggyun Na; nsghy@wku.ac.kr

Received 6 August 2019; Revised 23 January 2020; Accepted 9 March 2020; Published 15 May 2020

Academic Editor: Kemal Polat

Copyright (C) 2020 Lei Guo et al. This is an open access article distributed under the Creative Commons Attribution License, which permits unrestricted use, distribution, and reproduction in any medium, provided the original work is properly cited.

In recent years, Chinese economic development has slowed down and competition in the financial industry has become increasingly fierce. The purpose of this paper is to study the efficiency characteristics of China's banking industry in the new environment and provide suggestions for banks to improve efficiency. This paper uses a data envelopment analysis (DEA) SBMundesirable model and window analysis to measure the technical efficiency of 13 nationwide commercial banks in China during the period from 2008 to 2017. Furthermore, the convergence characteristics of bank technical efficiency are examined. The empirical results show that state-owned banks were more efficient than joint stock banks before 2012. After 2012, state-owned banks were less efficient than joint stock banks. Finally, this paper explores the influential factors of technical efficiency. Noninterest income ratio, net interest margin, growth rate of total investment in fixed assets, and consumer price index have a significant positive impact on bank efficiency. The cost-to-income ratio has a significant negative impact on bank efficiency. Further research using the threshold model shows that noninterest income ratio has a threshold effect on bank efficiency.

\section{Introduction}

The banking sector is the key to stabilize the macroeconomics of the nation. The sector provides credit and financial services to other economic sectors to achieve rapid and stable economic development [1]. In the last ten years, the external environment of the Chinese banking sector has undergone tremendous changes. First, the growth rate of China's economy is slowing down. According to statistics from the China National Bureau of Statistics (2018), the GDP growth rate has dropped from $9.7 \%$ in 2008 to $6.9 \%$ in 2015 and has maintained at this level in recent years. Traditional industries such as steel, coal, and cement have overcapacity, and these industries have received a large number of bank loans in their development. As the economic growth slows down, industries with overcapacity are facing losses, which will affect the bank's credit scale and credit risk, thereby adversely affecting the operating efficiency of the banking industry [2]. On the other hand, China has accelerated the reform of interest rate liberalization. Since 2012, China has deregulated interest rates on financial institutions and gradually implemented marketization of interest rates. With the marketization of interest rates, commercial banks are faced with the impact of interest rate spread and profit reduction [3]. Therefore, it is necessary to study the efficiency of commercial banks and its influencing factors in order to improve the efficiency and adapt to the complex external environment.

Measuring the efficiency of banks is not an easy task. This involves the evaluation of multiple inputs and multiple outputs. Data envelopment analysis (DEA) is a linear programming method used to measure the efficiency of organizations and is also an effective method for measuring the efficiency of organizations [4]. DEA does not need to set the 
production function form and can well measure the efficiency of a system with multiple inputs and outputs. It is the most widely used technology for assessing bank efficiency [5].

There are more and more studies on the efficiency of China's banking industry. Yang and Zhang [6] used data envelopment analysis to study the cost efficiency and profit efficiency of Chinese commercial banks. The conclusion was that joint stock banks were less efficient than state-owned commercial banks, but the efficiency of joint stock banks grew faster. Tan and Floros [7] studied efficiency of Chinese commercial banks and found that compared with stateowned commercial banks, joint stock commercial banks and city commercial banks had lower technical efficiency. Gan [8] applied the SBM model and controlled the influence of external environmental factors and analyzed the efficiency of 16 large banks in China. Shyu et al. [9] used the three-stage data envelopment analysis (DEA) model to explore the true managerial efficiency of the banking firms in Taiwan, Hong Kong, and Mainland China.

Considering only loan quantity but neglecting loan quality may lead to deviation in the evaluation process. In recent years, the impact of nonperforming loans on the efficiency of Chinese Banks has attracted the attention of scholars. Tan and Tuo [10] calculated the efficiency of Chinese commercial banks by taking nonperforming loans and SBM models into account, and the results showed that ignoring nonperforming loans significantly overestimated the efficiency of banks. Wang and Zhu [11] used SBM directional distance function to measure the efficiency of 11 listed commercial banks in China under the constraint of nonperforming loans from 2003 to 2009. The results show that the efficiency of the joint stock commercial banks is better than that of the large state-owned commercial banks, and the nonperforming loans are the main reason for the banks' inefficiency. Zhang et al. [12] applied directional distance function and superefficient DEA model to measure the efficiency of 11 listed commercial banks in China under the constraint of nonperforming loans. Zhang and Luo [13] used SBM-undesirable model and Bootstrap technology to measure the efficiency of 54 city commercial banks in China from 2010 to 2014. The above literature is all about measuring the static efficiency of banks. These DEA models can only analyze cross-sectional data, and the efficiency in different periods is not comparable.

In terms of dynamic evaluation of bank efficiency, Charnes et al. [14] combined the DEA model with window analysis to evaluate DMU efficiency trends. This method treats the same DMU in different periods as different DMUs. It puts the DMUs of several periods together to measure efficiency and finally uses the moving average method to calculate the moving average efficiency of each window period. The resulting efficiency values can be used to analyze the efficiency of the cross section for each period and also can be used to analyze the variation trend of efficiency [15]. When using window analysis to evaluate efficiency, it will increase the number of DMUs participating in the evaluation, so the discriminative power of the method is enhanced [16]. This method has better applicability in the case of small sample size [17]. To the best of our knowledge, only a few kinds of literature $[16,18,19]$ use DEA window analysis to analyze bank efficiency, but they all use a combination of radial DEA model and window analysis. Nonradial DEA window analysis has been widely used in insurance company efficiency, technological innovation efficiency, and energy efficiency research but has not been used for bank efficiency evaluation.

The aim of the paper is intended to combine the SBMundesirable model with window analysis to measure the efficiency and evolution of Chinese nationwide banks. This paper compares and analyzes the efficiency of each bank and divides the efficiency changes into four types. Then, it analyzes the convergence characteristics of bank efficiency. This paper also studies the influencing factors of bank efficiency and the threshold effect of noninterest income and bank efficiency.

This article extends the previous research as follows:

(1) This paper uses the SBM-undesirable model to combine with window analysis. The DEA window analysis method is suitable for horizontal and vertical analysis of efficiency, and SBM-undesirable model can consider the influence of nonperforming loans of Chinese banking efficiency. This method has not been used in bank efficiency analysis.

(2) The influencing factors of the efficiency of China's banking industry were cross-tested using different estimation techniques such as Tobit regression and Bootstrap truncation regression.

(3) In terms of influencing factors of efficiency, due to fierce competition in traditional businesses and banks' emphasis on developing new businesses, noninterest income is becoming increasingly important for banks. According to the 2017 bank financial report, the average noninterest income accounted for $31.9 \%$ of operating income. This paper studies the threshold effect of noninterest income ratio (NIIR) on efficiency. When NIIR level is low, the positive effect is small. When NIIR level is high, NIIR has a greater positive impact on bank efficiency.

(4) Select 13 nationwide banks data from China as a sample, and regional banks are not included in this study. According to the Law on Commercial Banks, commercial banks in China are divided into nationwide commercial banks and regional banks according to the scope of business activities. Nationwide commercial banks can carry out financial business nationwide. Regional commercial banks generally can only set up branches in specific regions to carry out financial business. Previous studies have selected several regional banks and nationwide banks to analyze together, but nationwide banks and regional banks have differences in terms of business scope and regulatory systems. A separate analysis of nationwide banks can ensure the rationality of efficiency evaluation and analysis of influencing factors. 
The results show that the efficiency of state-owned banks was slightly higher than that of joint stock banks from 2008 to 2011, and the efficiency of state-owned banks was lower than that of joint stock banks from 2012 to 2017. In addition, the technical efficiency convergence test indicates that the overall sample bank does not show $\sigma$ convergence trend and absolute $\beta$ convergence, but there is conditional $\beta$ convergence. The research results further show that the noninterest income ratio (NIIR), net interest margin (NIM), cost-to-income ratio (CIR), Total Investment in Fixed Assets (TIFA), and consumer price index (CPI) have significant effects on the efficiency of the Chinese banking industry. Finally, the threshold effect analysis shows that noninterest income ratio (NIIR) has a threshold effect on bank efficiency. When NIIR level is low, the positive effect is small. When NIIR level is high, NIIR has a greater positive impact on bank efficiency.

\section{Methodology and Data}

2.1. Model Selection. When the radial DEA model measures the inefficiency value, it is assumed that the input and output factors are adjusted in the same proportion, which is inconsistent with the actual production activity. At the same time, the efficiency of the DMU is overestimated without considering the effects of slack variables when evaluating DMU efficiency. Tone [20] proposed the Slack-Based Measure (SBM) model, which can solve the problems described above well:

$$
\begin{aligned}
E= & \min \rho=\frac{1-(1 / m) \sum_{i=1}^{m}\left(s_{i}^{-} / x_{i k}\right)}{1+(1 / q) \sum_{r=1}^{q}\left(s_{r}^{+} / y_{r k}\right)}, \\
& \text { s.t. } \\
& X \lambda+s^{-}=x_{k} \\
& Y \lambda-s^{+}=y_{k} \\
& \lambda, s^{-}, s^{+} \geq 0 .
\end{aligned}
$$

In equation (1), it is assumed that there are $n$ decision making units, each of which has $m$ types of input factors $(i=1,2, \ldots, m)$ and $q$ types of output factors $(r=1,2, \ldots, q) . E$ denotes the efficiency score, $\lambda$ is the weight vector, $s_{i}^{-}$is the slack variable of the input factor $i$, and $s_{r}^{+}$is the slack variable of the output factor $r$.

The SBM model defined by Tone containing the undesirable output is expressed as

$$
E=\min \rho=\frac{1-(1 / m) \sum_{i=1}^{m}\left(s_{i}^{-} / x_{i k}\right)}{1+\left(1 /\left(q_{1}+q_{2}\right)\right)\left[\sum_{r=1}^{q_{1}}\left(s_{r}^{+} / y_{r k}\right)+\sum_{r=1}^{q_{2}}\left(s_{t}^{b-} / b_{r k}\right)\right]},
$$

s.t.

$$
\begin{aligned}
& X \lambda+s^{-}=x_{k} \\
& Y \lambda-s^{+}=y_{k} \\
& B \lambda+s^{b-}=b_{k} \\
& \lambda, s^{-}, s^{+} \geq 0 .
\end{aligned}
$$

In equation (2), it is assumed that there are $n$ decision making units, each of which has $m$ types of input factors $(i=1,2, \ldots, m), q_{1}$ types of good output factors $(r=1,2, \ldots, q)$, and $q_{2}$ types of undesirable output factors $(r=1,2, \ldots, q) . E$ denotes the efficiency score, $\lambda$ is the weight vector, $s_{i}^{-}$is the slack variable of the input factor $i, s_{r}^{+}$is the slack variable of the output factor $r$, and $s_{t}^{b-}$ is the slack variable of the undesirable output factor $t$.

The SBM-undesirable model can only be used to measure the efficiency of a single year, which belongs to crosssectional data and is not comparable between different years. In this paper, the combination of the SBM-undesirable model and window analysis can increase the number of DMUs in the reference set and improve the distinguishing ability of the model. On the other hand, the calculated efficiency values can be analyzed in cross section or in time series.

When performing DEA window analysis, first determine the window width $d$, which is the number of periods included in a window. This method implicitly assumes that there is no technical change in each window. Using a narrow window width can reduce this problem so that it is reasonable to assume that the technical changes in each window are negligible [21]. Most research literature sets $d=3$. If there are $n$ DMUs per period, $p$ periods, the window width is $d$. Then the number of DMUs in each window is $d * n$, and the total number of windows is $w=p-d+1$. Each DMU will get $d$ efficiency values on each window so that there will be multiple efficiency values at each point in time. Calculate the average of multiple efficiencies at each point in time, which is the efficiency of the DMU.

2.2. Data. Considering the availability and comparability of data, this paper selects 13 nationwide commercial banks in China, of which 5 are state-owned banks: Industrial and Commercial Bank of China (ICBC), Agricultural Bank of China (ABC), China Construction Bank (CCB), Bank of China (BOC), and Bank of Communications (BOCOM). There are also 8 banks that are joint stock banks: China Merchants Bank (CMB), Shanghai Pudong Development Bank (SPDB), China CITIC Bank (CITIC), Hua Xia Bank (HXB), China Everbright Bank (CEB), China Minsheng Banking Corporation (CMBC), Industrial Bank (IB), and Ping An Bank (PAB). The data of this study comes from WIND database and China Statistical Yearbook. Since 2008, these commercial banks have adopted the new accounting standards to prepare financial reports, so this article opts 2008-2017 as the research period.

2.3. Index Selection. In addition to selecting the appropriate method, efficiency assessments must also select input and output indicators. When evaluating bank efficiency, scholars generally use the production method, the intermediary method, or a combination of the two methods to select indicators. The production method is more suitable for evaluating the efficiency of branches; the intermediary method is suitable for assessing the efficiency of the overall financial institution [22]. Because these two methods have 
limitations and cannot fully reflect the dual roles of financial institutions. Therefore, there is no consensus on the choice of input and output indicators for commercial banks. This paper draws on the method of Wang and Zhu [11]. Based on the production method and the intermediary method, the index is selected based on the availability of data and the correlation of index variables. Consequently, the inputs are net fixed assets, business and management fees, and total deposits. The good outputs are net interest income and noninterest income. Nonperforming loans are used as undesirable output.

The reasons for choosing input and output indicators are as follows. Fixed assets mainly measure the banks' establishment of branches to expand the scale of operations, as well as the increase of software and hardware equipment to improve service efficiency. Fixed assets are very important and form the basis of bank operations (Wang and Zhu [23]). According to the research of Li and Gao [24], they selected 55 papers with high citation rate on the efficiency of China's banking industry, among which 31 adopted net fixed assets as the input. Therefore, this paper chooses fixed assets as the input. Business and management fees are the operating costs of China's banking industry, so they are treated as input. Noninterest income is the innovative business income of China's banking industry, and it is becoming increasingly important. According to the financial reports of banks, the ratio of noninterest income to operating income was $14.43 \%$ in 2008 and $31.9 \%$ in 2017 . So, this paper chose noninterest income as an output. Table 1 shows the inputs, outputs, and descriptive statistics.

In the DEA model, there is generally a significant positive correlation between input and output indicators. Because different input factors are invested in a certain proportion, and as the number of input increases, the output will increase. Table 2 shows that the Pearson coefficient between each input indicator, and a good output indicator is above 0.9 , which is highly positively correlated and reasonable. It is also reasonable that there is a weak positive correlation between undesirable output indicator (nonperforming loans) and the above indicators.

\section{Empirical Analysis}

3.1. Analysis of the Efficiency of Each Bank. This article uses the SBM-undesirable model and DEA window analysis, and the window width is 3 , a total of 8 windows. The efficiency of 13 nationwide commercial banks in 2008-2017 was measured using MaxDEA8.0 software. Taking Agricultural Bank of China (ABC) as an example, the calculated efficiency based on the combination of the SBM-undesirable model and window analysis is shown in Table 3. There are three values in each window, which represent the corresponding efficiency value of the bank in 3 years. The value of each column is the efficiency value of the bank in the same year. The average value of each column is calculated to obtain the annual efficiency value of the bank. The same method can calculate the efficiency of other banks (Table 4).

As can be seen from Table 4, the bank with the highest average efficiency is Industrial and Commercial Bank of
China (ICBC), with an average efficiency of 0.979 in 10 years, and eight years of efficiency values are in the frontier of technical efficiency. ICBC is the largest commercial bank in China. According to the bank's financial report, ICBC is highly profitable, with a ten-year average return on equity of $19.5 \%$, higher than the average level of these banks. The second highest average efficiency is Industrial Bank (IB), with an average efficiency of 0.973 in 10 years and seven years in the frontier of technical efficiency. Industrial Bank is one of the commercial banks with the most financial business licenses. It can engage in banking, trust, leasing, funds, consumer finance, futures, asset management, etc. The noninterest income of Industrial Bank is growing rapidly. The third place is Bank of China (BOC), with an average efficiency of 0.942 . BOC's noninterest income is very large. Noninterest income accounts for $30.8 \%$ of operating income, and the average level of these 13 banks is only $22.2 \%$. The efficiency of BOC decreased significantly from 2016 to 2017, mainly due to the significant decrease in noninterest income, which decreased by $18.41 \%$ year-on-year. The reason behind this is that in 2016 BOC sold its subsidiaries to obtain a large amount of investment income, but these are nonrecurring gains and losses and are not sustainable. Therefore, the investment income in 2017 returned to the level of 2015.

The lowest average efficiency is the Agricultural Bank of China $(\mathrm{ABC})$, with an average efficiency of only 0.559 . The annual efficiency has been at a low level of around 0.6. Many branches of the Agricultural Bank of China carry out rural financial business in rural areas, and the rural areas are relatively backward. Therefore, the profitability of the Agricultural Bank of China is relatively low. On the other hand, the Agricultural Bank of China has too many branches and employees, and the operating cost is the highest among these banks. The scale of loans of the Agricultural Bank of China is small, and the loan-to-deposit ratio is only about $60 \%$ on average, far lower than other banks, so the Agricultural Bank of China's efficiency is low. The average efficiency of China Bank of Communications (BOCOM) is also very low, only 0.679. In the past ten years, the efficiency of China Bank of Communications has been declining. From a business perspective, China Communications Bank's retail business has not experienced significant growth, and noninterest income has grown slowly. Although China Bank of Communications is a large state-owned bank, its scale is smaller than that of other state-owned banks, and it is closer to joint stock banks. As a state-owned bank, the management system of China Bank of Communications is not as good as a joint stock bank. For the above reasons, the efficiency of China Communications Bank is very low.

This study classifies banks according to the average efficiency and coefficient of variance. The average efficiency of each bank in the evaluation period is 0.761 and the average coefficient of variation is 0.107 . According to the average efficiency $(M)$ and coefficient of variance $(\mathrm{CV})$ of each bank in the evaluation period, commercial banks are divided into four types, which are efficient and stable type (M: 0.761 1, $\mathrm{CV}<0.107)$, inefficient and stable type $(M<0.761$, $\mathrm{CV}<0.107)$, efficient and fluctuating type $(M: 0.761 \sim 1$, 
TABLE 1: The descriptive statistics of the input and output indexes (unit: million yuan).

\begin{tabular}{|c|c|c|c|c|c|}
\hline Index types & Variable & Mean & Std. dev. & Min & Max \\
\hline \multirow{3}{*}{ Input } & Net fixed assets & 54840.94 & 62502.03 & 1674.92 & 220651 \\
\hline & Business and management fees & 60901.08 & 53907.95 & 5223.87 & 179992 \\
\hline & Total deposits & 4983279 & 4872905 & 360514 & 19226349 \\
\hline \multirow{3}{*}{ Output } & Net interest income & 151175.6 & 139631.2 & 12597.89 & 522078 \\
\hline & Noninterest income & 49565.41 & 50388.75 & 1322.45 & 204424 \\
\hline & Nonperforming loans & 50064.08 & 54807.68 & 1900 & 230834 \\
\hline
\end{tabular}

TABLE 2: Correlation coefficients between input and output indexes.

\begin{tabular}{|c|c|c|c|c|c|c|}
\hline & $\begin{array}{l}\text { Net fixed } \\
\text { assets }\end{array}$ & $\begin{array}{c}\text { Business and } \\
\text { management fees }\end{array}$ & $\begin{array}{c}\text { Total } \\
\text { deposits }\end{array}$ & $\begin{array}{l}\text { Net interest } \\
\text { income }\end{array}$ & $\begin{array}{c}\text { Noninterest } \\
\text { income }\end{array}$ & $\begin{array}{c}\text { Nonperforming } \\
\text { loans }\end{array}$ \\
\hline Net fixed assets & 1.000 & & & & & \\
\hline $\begin{array}{l}\text { Business and } \\
\text { management fees }\end{array}$ & $0.951^{* * *}$ & 1.000 & & & & \\
\hline Total deposits & $0.952^{* * *}$ & $0.983^{* * *}$ & 1.000 & & & \\
\hline Net interest income & $0.930^{* * *}$ & $0.987^{* * *}$ & $0.989^{* * *}$ & 1.000 & & \\
\hline Noninterest income & $0.920^{* * *}$ & $0.908^{* * *}$ & $0.933^{* * *}$ & $0.921^{* * *}$ & 1.000 & \\
\hline Nonperforming loans & $0.261^{* * *}$ & $0.323^{* * *}$ & $0.301^{* * *}$ & $0.302^{* * *}$ & $0.230^{* * *}$ & 1.000 \\
\hline
\end{tabular}

${ }^{*}$ Significance within the level of $10 \%$; ${ }^{* *}$ significance within the levels of $5 \% ;{ }^{* * *}$ significance within the levels of $1 \%$.

TABLE 3: ABC efficiency SBM-undesirable model and window analysis results.

\begin{tabular}{llllllllll}
\hline & 2008 & 2009 & 2010 & 2011 & 2012 & 2013 & 2014 & 2015 & 2016 \\
\hline Window1 & 0.607 & 0.604 & 0.663 & & & & & & \\
Window2 & & 0.533 & 0.591 & 0.683 & & & & \\
Window3 & & & 0.518 & 0.598 & 0.596 & & & \\
Window4 & & & & 0.581 & 0.574 & 0.582 & & \\
Window5 & & & & & 0.559 & 0.568 & 0.613 & & \\
Window6 & & & & & & 0.504 & 0.543 & 0.534 & \\
Window7 & & & & & & & 0.543 & 0.534 & 0.470 \\
Window8 & & & & & & & 0.534 & 0.470 & 0.507 \\
Mean & 0.607 & 0.569 & 0.591 & 0.621 & 0.576 & 0.551 & 0.566 & 0.534 & 0.470 \\
\hline
\end{tabular}

TABle 4: Technical efficiency of 13 banks.

\begin{tabular}{lccccccccccc}
\hline Bank & 2008 & 2009 & 2010 & 2011 & 2012 & 2013 & 2014 & 2015 & 2016 & 2017 & Mean \\
\hline ICBC & 1 & 0.847 & 0.947 & 1 & 1 & 1 & 1 & 1 & 1 & 1 \\
IB & 1 & 0.845 & 0.957 & 0.932 & 1 & 1 & 1 & 1 & 1 & 1 \\
BOC & 1 & 0.94 & 0.96 & 1 & 1 & 1 & 0.924 & 0.876 & 1 & 0.724 & 0.973 \\
CMBC & 0.925 & 1 & 0.763 & 0.902 & 1 & 1 & 1 & 1 & 0.889 & 0.823 & 0.93 \\
SPDB & 0.806 & 0.716 & 0.798 & 0.895 & 0.87 & 0.988 & 0.906 & 0.787 & 1 & 1 & 0.876 \\
PAB & 0.919 & 0.791 & 0.718 & 0.72 & 0.775 & 0.808 & 1 & 1 & 1 & 0.881 & 0.861 \\
CMB & 0.849 & 0.664 & 0.717 & 0.743 & 0.711 & 0.75 & 0.942 & 0.937 & 0.922 & 0.815 & 0.805 \\
CITIC & 1 & 0.652 & 0.717 & 0.849 & 0.765 & 0.712 & 0.714 & 0.772 & 0.815 & 0.885 & 0.788 \\
CCB & 1 & 0.805 & 0.841 & 0.866 & 0.755 & 0.649 & 0.613 & 0.628 & 0.691 & 0.624 & 0.747 \\
CEB & 0.799 & 0.628 & 0.66 & 0.701 & 0.718 & 0.632 & 0.691 & 0.791 & 0.743 & 0.725 & 0.709 \\
BOCOM & 0.9 & 0.767 & 0.794 & 0.752 & 0.668 & 0.623 & 0.588 & 0.564 & 0.552 & 0.58 & 0.679 \\
HXB & 0.808 & 0.649 & 0.661 & 0.679 & 0.663 & 0.639 & 0.632 & 0.569 & 0.605 & 0.655 & 0.656 \\
ABC & 0.607 & 0.569 & 0.591 & 0.621 & 0.576 & 0.551 & 0.566 & 0.534 & 0.47 & 0.507 & 0.559 \\
\hline
\end{tabular}

$\mathrm{CV}>0.107)$, and inefficient and fluctuating type $(M<0.761$, $\mathrm{CV}>0.107$ ), respectively (Figures $1-4$ ).

First, the efficient- and stable-type banks are ICBC, BOC, CMBC, and IB. The efficiency of these banks declined in 2009. The average efficiency and trend of ICBC and IB are almost exactly the same.

Second, the inefficient- and stable-type banks are ABC, $\mathrm{CEB}$, and $\mathrm{HXB}$, one of which is a state-owned bank and two are joint stock banks. For example, the average efficiency of the Agricultural Bank of China is only 0.559, the highest efficiency is only 0.607 , and the annual fluctuation is small.

Third, the efficient- and fluctuating-type banks with high efficiency but high volatility are $\mathrm{PAB}$ and SPDB. The efficiency of these banks was highly volatile during the sample period. The change in efficiency takes the shape of an "S." 


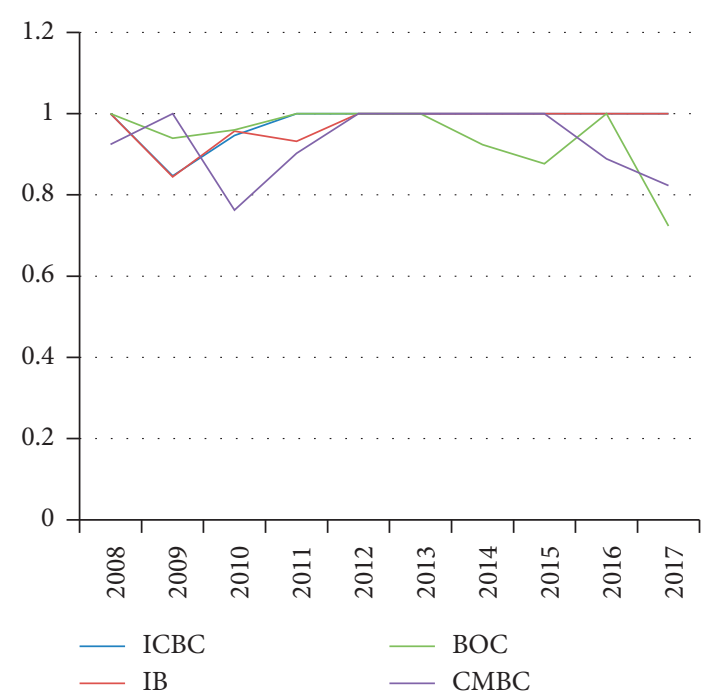

Figure 1: Efficient and stable type.

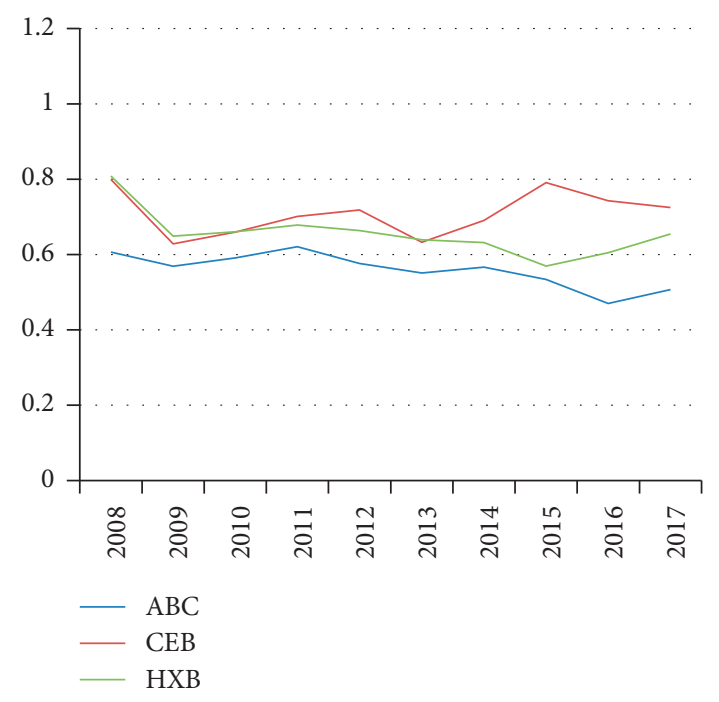

Figure 2: Inefficient and stable type.

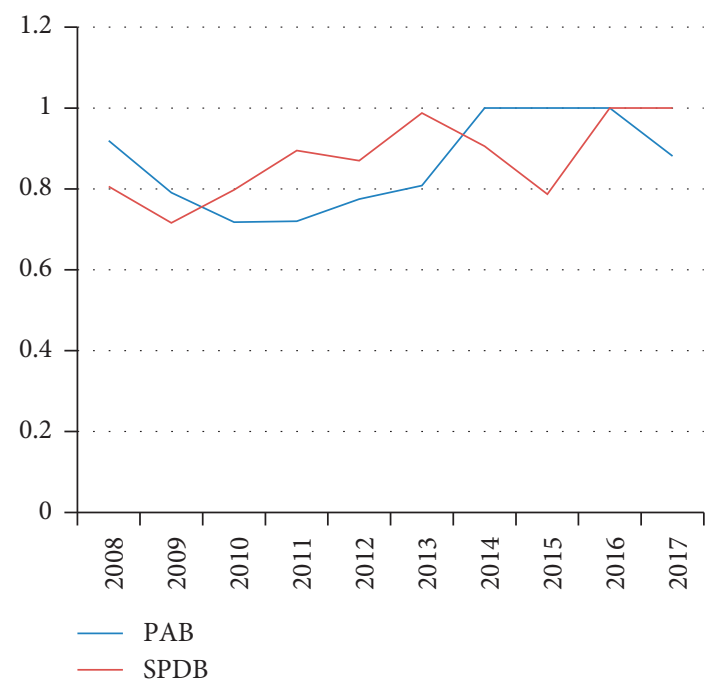

Figure 3: Efficient and fluctuating type.

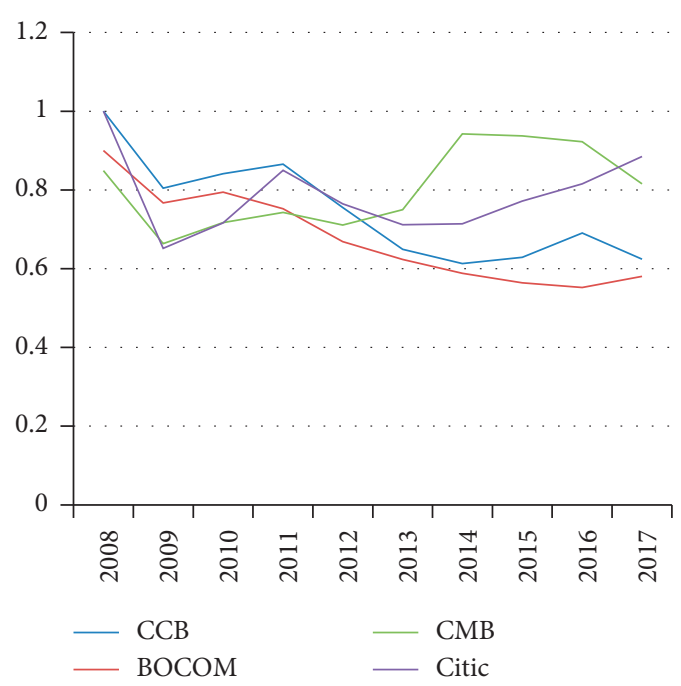

Figure 4: Inefficient and fluctuating type.

The highest efficiency reaches 1 and the lowest is only 0.72 , indicating that the efficiency of these banks is unstable.

Fourth, inefficient- and fluctuating-type banks with low efficiency and high volatility are CCB, BOCOM, CMB, and CITIC. During the sample period, the efficiency of CCB and BOCOM has continued to decline. The efficiency of the other two banks has continued to fluctuate.

3.2. Analysis of the Trends in the Efficiency of State-Owned Banks and Joint Stock Banks. Table 5 reports the efficiency of state-owned banks and joint stock banks between 2008 and 2017. The trend of efficiency changes is shown in Figure 5. Due to the impact of the international financial crisis in 2008 , the average efficiency of sample banks in 2009 dropped sharply. In 2011, the efficiency of sample banks began to rise. After that, the average efficiency of sample banks remained basically stable.

We also find that from 2008 to 2011, state-owned banks were more efficient than joint stock banks. Since 2012, the efficiency of state-owned banks has been declining, and the efficiency of state-owned banks is lower than that of joint stock Banks. On the other hand, due to the financial crisis, the efficiency of joint stock banks has declined. Since 2011, the efficiency of joint stock banks has gradually increased, and there has been a slight decline in 2017. Previous literature $[10,25]$ found that state-owned banks were less efficient than joint stock banks, while Tan and Anchor [26] found that joint stock banks were less efficient. The existence of different conclusions may be due to different research periods and the fact that the bank samples studied are not completely consistent.

All in all, the efficiency of state-owned banks was slightly higher than that of joint stock banks from 2008 to 2011, and the efficiency of state-owned banks was lower than that of joint stock banks from 2012 to 2017. The efficiency gap between the two tends to widen. Since 2012, it has been the period when China's economic growth rate has been declining. The GDP growth rate has dropped from $9.5 \%$ in 
TABLE 5: Efficiency of state-owned banks and joint stock banks.

\begin{tabular}{lccccccccccc}
\hline Bank & 2008 & 2009 & 2010 & 2011 & 2012 & 2013 & 2014 & 2015 & 2016 & 2017 & Mean \\
\hline State-owned & 0.901 & 0.785 & 0.826 & 0.848 & 0.800 & 0.765 & 0.738 & 0.721 & 0.743 & 0.687 & 0.781 \\
Joint stock & 0.888 & 0.743 & 0.749 & 0.803 & 0.813 & 0.816 & 0.861 & 0.857 & 0.872 & 0.848 & 0.825 \\
Mean & 0.895 & 0.764 & 0.788 & 0.825 & 0.806 & 0.790 & 0.799 & 0.789 & 0.807 & 0.767 & 0.803 \\
\hline
\end{tabular}

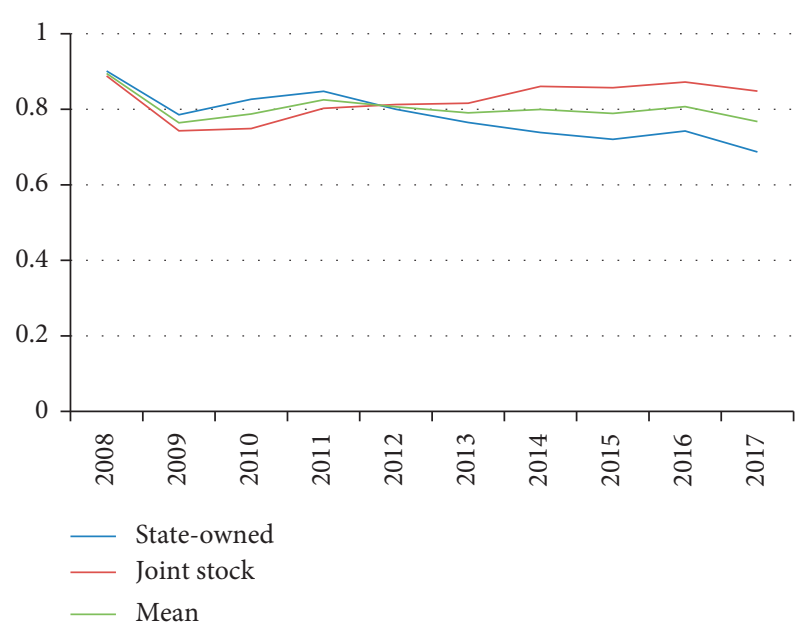

FIgURE 5: Efficiency trends.

2011 to $7.9 \%$ in 2012 and has since dropped to $6.9 \%$. At the same time, bank interest rates are deregulated and competition is becoming increasingly fierce. Therefore, the evolution of bank efficiency shows that state-owned banks are more susceptible to changes in the external environment, and joint stock banks are better able to cope with the adverse external environment and maintain sustainable development.

\subsection{Convergence Characteristics of Bank Technical Efficiency.} From the previous analysis, we can find that there are obvious gaps in the efficiency of different banks. Will these gaps gradually shrink? Convergence analysis can answer this question. Convergence phenomena fall into two categories: $\sigma$ convergence and $\beta$ convergence, where $\beta$ convergence includes absolute $\beta$ convergence and conditional $\beta$ convergence.

3.3.1. $\sigma$ Convergence Test. The $\sigma$ convergence is judged by analyzing the trend of the standard deviation of bank efficiency. If the standard deviation gradually decreases with time, there is $\sigma$ convergence. $\sigma$ Convergence means that the efficiency gap between banks is shrinking.

As shown in Figure 6, no matter state-owned bank or joint stock bank, $\sigma$ is increasing, and there is no $\sigma$ convergence. This means that the efficiency gap between banks is not only not narrowing, but also increasing.

3.3.2. Absolute $\beta$ Convergence Test. Referring to the study by Barro and Sala-i-Martin [27], absolute $\beta$ convergence can be inferred using the following regression model:

$$
\frac{\ln \left(T E_{i, t} / T E_{i, 0}\right)}{T}=\alpha+\beta \ln T E_{i, 0}+\varepsilon_{i t},
$$

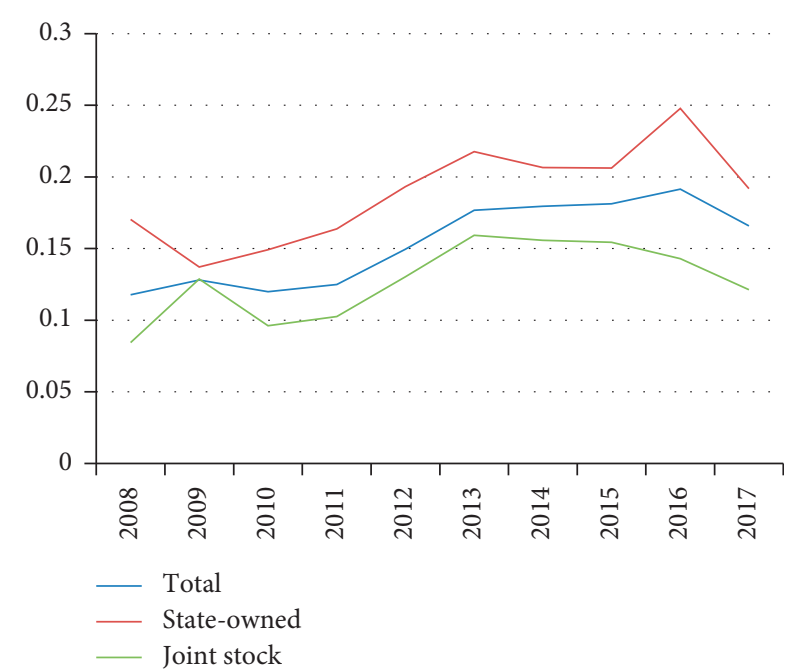

Figure 6: $\sigma$ convergence trend.

where $T E_{i, t}$ denotes the efficiency score of bank $i$ at time $t$, $T E_{i, 0}$ denotes the initial efficiency score of bank $i, T$ is the time span of the observation period, $\alpha$ is a constant term, $\beta$ is a convergence coefficient, and $\varepsilon_{i t}$ is the error term. A significant negative $\beta$ indicates that there is absolute $\beta$ convergence. This suggests that banks with lower efficiency will have faster growth rates and will eventually catch up with efficient banks, and the efficiency of different banks will converge to the same level. The larger the absolute value of $\beta$, the greater the convergence tendency.

Due to the small sample size, this paper only performs OLS regression on the whole sample bank. The regression coefficient of $\beta$ is -0.0209 , and the $P$ value is 0.639 , which indicates that there is no absolute $\beta$ convergence, which is consistent with the previous $\sigma$ convergence conclusion.

3.3.3. Conditional $\beta$ Convergence Test. According to the research method of Miller and Upadhyay [28], the conditional $\beta$ convergence regression equation is established:

$$
\ln \left(T E_{i, t} / T E_{i, t-1}\right)=\alpha+\beta \ln T E_{i, t-1}+\varepsilon_{i t},
$$

where $T E_{i, t}$ denotes the efficiency score of bank $i$ at time $t$, $T E_{i, t-1}$ denotes the efficiency score of bank $i$ at time $t-1, \alpha$ is a constant term, $\beta$ is a convergence coefficient, and $\varepsilon_{i t}$ is the error term. The parameters are estimated using the fixedeffects panel data estimation method. If $\beta$ is significantly negative, it indicates that there is conditional $\beta$ convergence. Conditional $\beta$ convergence measures whether the efficiency of the bank converges to its respective level of stability.

Table 6 reports the estimation results of the conditional $\beta$ convergence for the full sample. The conditional $\beta$ 
TABLE 6: Conditional $\beta$ convergence test (fixed-effects panel data).

\begin{tabular}{lcccc}
\hline & Coef. & Std. err. & $t$ & $P>|t|$ \\
\hline$\beta$ & $-0.5689^{* * *}$ & 0.0816 & -6.97 & 0.000 \\
_cons & $-0.1457^{* * *}$ & 0.0206 & -7.09 & 0.000 \\
F & & $48.59(0.0000)$ & & \\
R-sq & & 0.3205 & & \\
\hline
\end{tabular}

*Significance within the level of $10 \%$; ${ }^{* *}$ significance within the level of $5 \%$; *** significance within the level of $1 \%$.

convergence regression coefficient is -0.5689 and statistically significant at $1 \%$ level. It indicates that there is a conditional $\beta$ convergence, and the efficiency of each bank will converge to its stable level.

\subsection{Empirical Analysis of Factors Affecting the Efficiency}

3.4.1. Tobit Regression. As mentioned previously, there are obvious differences in the efficiency of different banks. To analyze the factors that affect efficiency, we need to use statistical methods. Since bank efficiency is a limited dependent variable, the adoption of OLS can lead to bias in the estimation results. For the robustness of the results, this paper uses the panel Tobit model to analyze the factors affecting efficiency empirically.

There are no unified conclusions on the factors affecting bank efficiency. Some researchers study the factors of the bank itself, and some researchers study the external factors. Fukuyama and Matousek [29] believe that using the internal indicators of banks to analyze efficiency factors may miss some macroeconomic factors, and macroeconomic factors are also one of the important factors affecting bank efficiency. Therefore, we study the factors affecting bank efficiency from both macro and micro aspects.

For the micro factors that affect bank efficiency, refer to the study by Zhang and Wang [30]. And according to the management theory of commercial banks, this paper selects five factors: innovation capability, traditional business profitability, and cost management capability. Noninterest income ratio (NIIR) represents innovation capability, costto-income ratio (CIR) represents cost management capability, and net interest margin (NIM) represents traditional business profitability.

For the macrofactors affecting bank efficiency, refer to the study by Zhang and Wang and Zhu et al. [30, 31] to select the growth rate of total investment in fixed assets (TIFA) and consumer price index (CPI). The data comes from the WIND database and China Statistical Yearbook.

Taking into account the above factors, we established a Tobit regression model to analyze the relationship between bank technical efficiency (TE) and various influencing factors:

$$
\begin{aligned}
T E_{i t}= & \beta_{0}+\beta_{1} N I I R_{i t}+\beta_{2} C I R_{i t}+\beta_{3} N_{I} M_{i t} \\
& +\beta_{4} T I F A_{i t}+\beta_{5} C P I_{i t}+\varepsilon_{i t},
\end{aligned}
$$

where $T E_{i t}$ indicates the technical efficiency of the bank $i$ at time $t$, and the symbol on the right-hand side of the equation is the corresponding influencing factor. $\beta_{0} \beta_{1}, \ldots, \beta_{5}$ are parameters to be estimated, and $\varepsilon_{i t}$ is the random error.
Since this study is panel data, it is important to choose the correct panel technology method and interpret the results according to the chosen method. The likelihood ratio (LR) test method is used to determine whether the pooled effect or the random effect is appropriate. The LR test indicates that a random-effects model should be used. Therefore, the results of the study will be explained based on the results of random effects. The estimated results of the Tobit regression model are shown in Table 7.

The estimation results in Table 7 are analyzed as follows. Among the microinfluence factors, noninterest income ratio (NIIR), cost-to-income ratio (CIR), and net interest margin (NIM) have significant impacts on bank efficiency.

(1) Noninterest Income Ratio (NIIR). The bank's NIIR reflects the bank's ability to innovate. As the ability to innovate increases, the scale of off-balance sheet activities increases, and the higher the proportion of noninterest income, the higher the efficiency of the bank. The Industrial Bank's, with the highest average efficiency, noninterest income ratio in 2017 was $36.81 \%$. The lowest average was that of the Agricultural Bank of China; the noninterest income ratio in 2017 was only $17.71 \%$. In model estimation, NIIR has a significant positive impact on TE, indicating that bank innovation improves bank efficiency. The conclusion of this study is the same as that of Lu and Li [2].

(2) The Cost-to-Income Ratio (CIR). The cost-to-income ratio reflects the level of cost management capabilities of commercial banks. CIR has a significant negative impact on $\mathrm{TE}$, indicating that costs are falling and banks' efficiency will increase. Industrial Bank's lowest cost-to-income ratio is $21.59 \%$, but the Agricultural Bank of China's cost-to-income ratio is at least $32.96 \%$. So, the efficiency of the two banks is very different.

(3) Net Interest Margin (NIM). NIM has a significant positive impact on TE. $70 \%$ of the income of the Chinese banking industry comes from interest income, and interest income has a very important position in operating income. NIM is the difference between bank loan rates and deposit rates. NIM represents the profitability of traditional business, which is an important indicator affecting the efficiency of Chinese commercial banks [32].

Among the macroinfluence factors, the growth rate of total investment in fixed assets (TIFA) and consumer price index (CPI) have a significant positive impact on bank efficiency.

(1) Growth Rate of Total Investment in Fixed Assets (TIFA). TIFA has a significant positive impact on TE. Investment in fixed assets in China is an important factor to promote economic growth. The financing channels of Chinese enterprises are mainly bank credits, so loans from commercial banks constitute the main source of funds for investment in fixed assets in the whole society. The increase in TIFA will 
TABLE 7: Tobit regression results for impact factor analysis of technical efficiency.

\begin{tabular}{lcccc}
\hline Variables & Coef. & Std. err. & $z$ & $P>|z|$ \\
\hline NIIR & $0.0159^{* * *}$ & 0.0024 & 6.63 & 0.000 \\
CIR & $-0.0105^{* * *}$ & 0.0036 & -2.95 & 0.003 \\
NIM & $0.1512^{* * *}$ & 0.0414 & 3.65 & 0.000 \\
TIFA & $0.0117^{* * *}$ & 0.0022 & 5.26 & 0.000 \\
CPI & $0.0139^{* * *}$ & 0.0051 & 2.71 & 0.007 \\
_cons & $-1.1820^{* *}$ & 0.5270 & -2.24 & 0.025 \\
\hline
\end{tabular}

*Significance within the level of $10 \%$; ${ }^{* *}$ significance within the levels of $5 \%$; ${ }^{* * *}$ significance within the level of $1 \%$.

definitely increase the scale of bank loans, which will help improve the efficiency of banks. An empirical study by Wang and Zhu [23] supports this conclusion.

(2) Consumer Price Index (CPI). CPI has a significant positive impact on TE. This result is consistent with the findings of Tan and Anchor [26], but contrary to the conclusions of Yuan and Zhang [33]. CPI is an important indicator of inflation. Moderate inflation will promote economic development, while large inflation will have side effects on national economic growth and affect the stable operation of the banking industry. From 2008 to 2017, the CPI in China was between $1 \%$ and $6 \%$, which is considered moderate inflation. Therefore, it is beneficial to the economic development and the improvement of banking efficiency. The different conclusions of Yuan and Zhang [33] may be related to the different research period. The period they studied was from 1999 to 2006. During this period, most of China's CPI was around $1 \%$ or even less than 0 , which may have a negative impact on bank efficiency.

3.4.2. Robust Test. In order to test the robustness of the above conclusions, we employ a Bootstrap truncated regression model. Simar and Wilson [34] believed that in the traditional DEA two-stage method, there was a serial correlation between dependent variables (efficiency values), and there was also correlation between environmental variables and random interference variables. Therefore, they proposed to adopt Bootstrap truncated regression model. Simar and Wilson described the detailed steps for Bootstrap truncated regression model, so we have omitted the details here. Table 8 shows that with Bootstrap truncation regression, there is no significant change in the relationship between each independent variable and the efficiency value, indicating that the conclusion is robust.

3.4.3. Further Study on the Threshold Model. In the above discussion, the noninterest income ratio (NIIR) represents the bank's ability to innovate. We found that the bank's ability to innovate has a positive effect on efficiency. Among these banks, the noninterest income ratio is also increasing. Bank financial report data show that the average noninterest income ratio in 2008 was only $14.43 \%$, while it reached
TABLE 8: Bootstrap truncated regression results for impact factor analysis of technical efficiency.

\begin{tabular}{lcccc}
\hline Variables & Coef. & Std. err. & $z$ & $P>|z|$ \\
\hline NIIR & $0.0100^{* * *}$ & 0.0023 & 4.42 & 0.000 \\
CIR & $-0.0118^{* * *}$ & 0.0028 & -4.24 & 0.000 \\
NIM & 0.0237 & 0.0405 & 0.58 & 0.559 \\
TIFA & $0.0141^{* * *}$ & 0.0023 & 6.04 & 0.000 \\
CPI & $0.0201^{* * *}$ & 0.0072 & 2.80 & 0.005 \\
_cons & $-1.4450^{* *}$ & 0.7267 & -1.99 & 0.047 \\
\hline
\end{tabular}

*Significance within the levels of $10 \%$; ${ }^{* *}$ significance within the level of $5 \%$; **** significance within the level of $1 \%$.

$31.9 \%$ in 2017. Regarding the relationship between noninterest income and the efficiency of commercial banks, some believe that the relationship is not significant [35], and some scholars believe that there is a significant linear relationship [36]. We speculate that there may be a nonlinear relationship between the two. This paper will use the panel threshold model to further study the nonlinear effect of noninterest income ratio on efficiency. The model proposed by Hansen [37]was adopted for analysis, the noninterest income ratio (NIIR) is selected as the threshold variable, and a single threshold model is established as follows:

$$
\begin{aligned}
T E_{i t}= & \mu_{i t}+\beta_{1} N I I R_{i t} I\left(N I I R_{i t} \leq \gamma\right) \\
& +\beta_{2} N I I R_{i t} I\left(N I I R_{i t}>\gamma\right)+\theta z_{i t}+\varepsilon_{i t},
\end{aligned}
$$

where $i$ represents banks; $t$ denotes the year; $T E_{i t}$ pertains to the dependent variable, which indicates the technical efficiency of the bank; $N I I R_{i t}$ refers to the independent variable, and $N I I R_{i t}$ is also the threshold variable; $\gamma$ stands for the threshold value to be estimated; $\varepsilon_{i t}$ denotes the random error; $\beta_{1}, \beta_{2}$, and $\theta$ represent the coefficients to be estimated for each variable; $z_{i t}$ refers to a group of control variables that have a significant effect on the technical efficiency, and we still use CIR, NIM, TIFA, and CPI as control variables; and I(.) pertains to the indicator function: when the condition in parentheses is satisfied, it is taken as 1; otherwise, it is taken as 0 .

This study investigates the nonlinear effect of NIIR on the technical efficiency of the bank. This study uses the Bootstrap to repeatedly sample 300 times for simulation. Through the threshold effect test, there is a single threshold effect. Table 9 provides the $F$ value and corresponding $P$ value of NIIR threshold significance test. The table shows that there is a single threshold effect at the significance level of $1 \%$, while the double threshold test is not significant. Therefore, there is a single threshold effect between the NIIR and the technical efficiency of the bank, and the threshold value and threshold value of the 95\% confidence interval are shown in Table 10 .

Table 10 shows the threshold model regression results when the NIIR is used as threshold variables. In different threshold regions, the effect of NIIR on bank efficiency will change. When the NIIR is lower than the threshold value $(N I I R=25.814 \%)$, NIIR has a significant positive effect on bank efficiency, where the marginal coefficient of the effect is 0. 0077. When the NIIR is higher than the threshold value, NIIR has a significant positive effect on bank efficiency, where the marginal coefficient of the effect is 0.0118 . Table 11 
TABLE 9: Threshold effect test.

\begin{tabular}{lccccc}
\hline Threshold & $f$ value & $P$ value & $10 \%$ & $5 \%$ & $1 \%$ \\
\hline Single & 30.21 & 0.0067 & 14.8250 & 17.1542 & 29.2033 \\
Double & 5.41 & 0.6100 & 14.1762 & 17.8631 & 26.2515 \\
\hline
\end{tabular}

TABLE 10: Threshold value estimates.

\begin{tabular}{lccc}
\hline Variables & Threshold value & Lower & Upper \\
\hline NIIR & 25.8140 & 25.3967 & 27.2029 \\
\hline
\end{tabular}

TABLE 11: Threshold model regression results.

\begin{tabular}{lcccc}
\hline Variables & Coef. & Std. err. & $t$ & $P>|Z|$ \\
\hline NIIR (NIIR $\leq 25.81)$ & $0.0077^{* * *}$ & 0.0021 & 3.72 & 0.000 \\
NIIR (NIIR $>25.81)$ & $0.0118^{* * *}$ & 0.0018 & 6.57 & 0.000 \\
CIR & $-0.0107^{* * *}$ & 0.0028 & -3.82 & 0.000 \\
NIM & $0.1393^{* * *}$ & 0.0314 & 4.44 & 0.000 \\
TIFA & $0.0120^{* * *}$ & 0.0017 & 6.88 & 0.000 \\
CPI & $0.0092^{* *}$ & 0.0037 & 2.47 & 0.015 \\
_cons & -0.5480 & 0.3825 & -1.43 & 0.155 \\
obs & 130 & & & \\
R-sq & 0.5596 & & & \\
f test & 23.5 & & & \\
Prob $>$ f & 0.0000 & & & \\
\hline
\end{tabular}

*Significance within the level of $10 \%$; ${ }^{* *}$ significance within the level of $5 \%$; ${ }^{* * *}$ significance within the level of $1 \%$.

shows that NIIR has a positive but nonlinear effect on bank efficiency. When the level of NIIR is high, NIIR has a large positive effect on bank efficiency; when the level of NIIR is low, the positive effect is small. In addition, the effect of other variables on efficiency is similar to the result of Tobit regression, which also indicates the robustness of the result.

\section{Conclusions and Limitations}

4.1. Conclusions. This study selects the data of 13 nationwide banks in China during the period 2008 to 2017 and uses the SBM-undesirable model and window analysis method to evaluate the efficiency of banks. The influencing factors were analyzed using Tobit regression and threshold model.

(1) Our research shows that in addition to the low efficiency of China's nationwide banks in 2009, the efficiency of other periods is relatively stable. Stateowned banks were more efficient than joint stock banks before 2012. Since 2012, the efficiency of stateowned banks is lower than that of joint stock banks, and the efficiency gap between the two tends to widen. The efficiency of state-owned banks is more susceptible to changes in the external environment, and joint stock banks are better able to cope with the adverse external environment and maintain sustainable development. Therefore, state-owned banks should improve efficiency and maintain stability.

(2) The technical efficiency convergence test indicates that the overall sample bank does not show $\sigma$ convergence trend and absolute $\beta$ convergence, but there is conditional $\beta$ convergence. This shows that the gap between efficient banks and inefficient banks is still very large, and the efficiency of the two does not converge, but the efficiency of each bank will converge to its stable level.

(3) Among the micro influence factors, noninterest income ratio (NIIR), net interest margin (NIM), and cost-to-income ratio (CIR) have significant impacts on bank efficiency. Among the macro influence factors, the growth rate of total investment in fixed assets (TIFA) and consumer price index (CPI) have a significant impact on bank efficiency. In this paper, the threshold model is used to further study the threshold effect of noninterest income ratio (NIIR). When NIIR is below the threshold (NIIR $=25.814 \%$ ), NIIR has a small positive effect on bank efficiency. When NIIR is above the threshold, NIIR has a greater positive impact on bank efficiency.

Against the background of the slowdown in Chinese economic growth and the increasingly fierce competition in the financial industry, some of the important managerial implications of this research are that Chinese nationwide commercial banks need to implement diversified business strategies, improve their innovation capabilities, and develop new businesses. Also, they need to expand the intermediary and off-balance-sheet business of commercial banks and increase the noninterest income of the banking industry. Commercial banks should control costs, reduce the cost-toincome ratio, increase loans while ensuring operational safety, and stabilize the profitability of traditional businesses.

\subsection{Limitations and Future Research}

(1) This paper studies the positive impact and threshold effect of banking business innovation on efficiency, without considering the risk brought by innovation. In future studies, innovation, risk, and bank efficiency can be combined for analysis.

(2) The DEA model adopted in this paper is a singlestage model, which cannot evaluate the efficiency of the bank's intermediate production process. In addition, some output factors, such as risk, belong to fuzzy data, so the network fuzzy DEA model can be considered to study efficiency in the future.

\section{Data Availability}

The data used to support the findings of this study are available from the corresponding author upon request.

\section{Conflicts of Interest}

The authors declare no conflicts of interest regarding the publication of this paper.

\section{Authors' Contributions}

L. G. and S. N. carried out conceptualization; L. G. carried out methodology and validation; X. T. carried out formal 
analysis; P. G. carried out investigation; L. G. carried out original draft preparation; S. N. carried out review and editing; C. L. carried out visualization; and S. N. carried out supervision.

\section{Acknowledgments}

This paper performance was supported by Wonkwang University in 2020.

\section{References}

[1] J. Y. Lin, X. Sun, and Y. Jiang, "Toward a theory of optimal financial structure in economic development," Economic Research Journal, vol. 8, pp. 4-17, 2009.

[2] Y. Lu and G. Li, "A study of TFP for commercial Bank of China in post-crisis era: malmquist index analysis based on DEA model," Journal of Shanxi University, vol. 5, pp. 94-104, 2018.

[3] H. J. Li, "Challenges and countermeasures of interest rate liberalization to commercial banks," International Finance Research, vol. 2, pp. 65-76, 2015.

[4] A. Emrouznejad, B. R. Parker, and G. Tavares, "Evaluation of research in efficiency and productivity: a survey and analysis of the first 30 Years of scholarly literature in DEA," SocioEconomic Planning Sciences, vol. 42, no. 3, pp. 151-157, 2008.

[5] M. D. Fethi and F. Pasiouras, "Assessing bank efficiency and performance with operational research and artificial intelligence techniques: a survey," European Journal of Operational Research, vol. 204, no. 2, pp. 189-198, 2010.

[6] D. Yang and A. Zhang, "Efficiency evaluation of Chinese commercial banks from 1996 to 2005: an empirical analysis based on cost efficiency and profit efficiency," Journal of Financial Research, vol. 12, pp. 102-112, 2007.

[7] Y. Tan and C. Floros, "Risk, competition and efficiency in banking: evidence from China," Global Finance Journal, vol. 35, pp. 223-236, 2018.

[8] X. Gan, "SBM analysis of the efficiency of Chinese commercial banks: controlling macro and ownership factors," Journal of Financial Research, vol. 10, pp. 58-69, 2007.

[9] J. Shyu, P.-T. Lieu, and W. Chang, "How the environment determines banking efficiency: a comparison of banking firms in Taiwan, Hong Kong, and Mainland China," International Transactions in Operational Research, vol. 22, no. 4, pp. 757-770, 2015.

[10] Z. Tan and M. Tuo, "Non-performing loans, capital adequacy ratio and efficiency of commercial banks," Finance Forum, vol. 10, pp. 40-50, 2016.

[11] B. Wang and N. Zhu, "Efficiency and total factor productivity of China's listed commercial banks under the constraint of non-performing loans: an empirical analysis based on SBM directional distance function," Journal of Financial Research, vol. 1, pp. 110-130, 2011.

[12] J. Zhang, P. Liao, and J. Xie, "Efficiency analysis of Chinese commercial banks under non-performing loan constraints," Journal of Jiangxi University of Finance and Economics, vol. 4, pp. 44-49, 2012.

[13] W. Zhang and H. Luo, "City commercial Bank operating efficiency, regional characteristics and industry dependence," Journal of University of Electronic Science and Technology of China, vol. 3, pp. 1-8, 2019.

[14] A. Charnes, C. T. Clark, W. W. Cooper, and B. Golany, "A developmental study of data envelopment analysis in measuring the efficiency of maintenance units in the U.S. air forces," Annals of Operations Research, vol. 2, no. 1, pp. 95-112, 1984.

[15] T. Jiang, L. Fan, and P. Jing, "Operating efficiency evaluation and improvement for China's life insurance companies under the two-stage perspective: based on network SBM model and DEA window analysis method," Insurance Studies, vol. 10, pp. 33-43, 2015.

[16] N. K. Avkiran, "Decomposing technical efficiency and window analysis," Studies in Economics and Finance, vol. 22, no. 1, pp. 61-91, 2004.

[17] S. Wang, S. Qiu, S. Ge, J. Liu, and Z. Peng, "Benchmarking toronto wastewater treatment plants using DEA window and tobit regression analysis with a dynamic efficiency perspective," Environmental Science and Pollution Research, vol. 25, no. 32, pp. 32649-32659, 2018.

[18] F. Sufian, "Trends in the efficiency of Singapore's commercial banking groups," International Journal of Productivity and Performance Management, vol. 56, no. 2, pp. 99-136, 2007.

[19] F. A. Shawtari, M. Abdelnabi Salem, and I. Bakhit, "Decomposition of efficiency using DEA window analysis," Benchmarking: An International Journal, vol. 25, no. 6, pp. 1681-1705, 2018.

[20] K. Tone, "A slacks-based measure of efficiency in data envelopment analysis," European Journal of Operational Research, vol. 130, no. 3, pp. 498-509, 2001.

[21] M. Asmild, J. C. Paradi, V. Aggarwall, and C. Schaffnit, "Combining DEA window analysis with the malmquist index approach in a study of the Canadian banking industry," Journal of Productivity Analysis, vol. 21, no. 1, pp. 67-89, 2004.

[22] A. N. Berger and D. B. Humphrey, "Efficiency of financial institutions: international survey and directions for future research," European Journal of Operational Research, vol. 98, no. 2, pp. 175-212, 1997.

[23] B. Wang and N. Zhu, "Total factor productivity growth in China banking industry under the constraint of nonperforming loans," Economic Research, vol. 5, pp. 32-45, 2011.

[24] S. J. Li and Y. Gao, "Input-output indicator selection in the empirical study of bank efficiency," Quantitative Economy Technical and Economic Research, vol. 31, pp. 130-144, 2014.

[25] X. Li and Z. Zheng, "Efficiency evaluation of the Chinese listed banks and its influential factors: based on two-stage SBM model," China Economic Studies, vol. 4, pp. 24-32, 2015.

[26] Y. Tan and J. Anchor, "The impacts of risk-taking behaviour and competition on technical efficiency: evidence from the Chinese banking industry," Research in International Business and Finance, vol. 41, pp. 90-104, 2017.

[27] R. J. Barro and X. Sala-i-Martin, "Convergence," Journal of Political Economy, vol. 100, no. 2, pp. 223-251, 1992.

[28] S. M. Miller and M. P. Upadhyay, "Total factor productivity and the convergence hypothesis," Journal of Macroeconomics, vol. 24, no. 2, pp. 267-286, 2002.

[29] H. Fukuyama and R. Matousek, "Efficiency of Turkish banking: two-stage network system. Variable returns to scale model," Journal of International Financial Markets, Institutions and Money, vol. 21, no. 1, pp. 75-91, 2011.

[30] J. Zhang and P. Wang, "Research on bank efficiency and its influencing factors: based on transnational comparison between Chinese and foreign banks," Journal of Financial Research, vol. 5, pp. 13-28, 2011.

[31] N. Zhu, B. Wang, and Z. Yu, "Shadow prices of non- performing loans of Chinese commercial banks under different risk preferences," Journal of Financial Research, vol. 6, pp. 67-81, 2014. 
[32] S. Ba and W. Zhong, "Definition and calculation of net interest margin of domestic and foreign commercial banks," China Banking, vol. 6, pp. 66-68, 2017.

[33] X. Yuan and B. Zhang, "The determinant's study of total factor productivity of China's commercial banks," The Journal of Quantitative \& Technical Economics, vol. 4, pp. 93-104, 2009.

[34] L. Simar and P. W. Wilson, "Estimation and inference in twostage, semi-parametric models of production processes," Journal of Econometrics, vol. 136, no. 1, pp. 31-64, 2007.

[35] L. Li, "The impact of non-interest income on the efficiency of China's banking sector," Journal of Stock and Forex Trading, vol. 3, pp. 1-8, 2014.

[36] C. Meslier, R. Tacneng, and A. Tarazi, "Is bank income diversification beneficial? Evidence from an emerging economy," Journal of International Financial Markets, Institutions and Money, vol. 31, pp. 97-126, 2014.

[37] B. E. Hansen, "Threshold effects in non-dynamic panels: estimation, testing, and inference," Journal of Econometrics, vol. 93, no. 2, pp. 345-368, 1999. 